\title{
Implant-based factor as possible risk for peri-implantitis
}

\author{
Daniela Leal \\ ZANDIM-BARCELOS(a) \\ Gabriel Garcia de CARVALHO(a) iD \\ Vitor Marques SAPATA ${ }^{(b)}$ \\ Cristina Cunha VILLAR(b) \\ Christoph HÄMMERLE(c) \\ Giuseppe Alexandre ROMITO(b) \\ (a) Universidade Estadual Paulista - Unesp, \\ Araraquara School of Dentistry, Department of \\ Diagnosis and Surgery, Araraquara, SP, Brazil. \\ (b) Universidade de São Paulo - USP, Dental \\ School, Department of Stomatology, São \\ Paulo, Brazil. \\ (c) University of Zurich, Clinic for Fixed and \\ Removable Prosthodontics and Dental \\ Material Science, Zurich, Switzerland.
}

Declaration of Interests: The authors certify that they have no commercial or associative interest that represents a conflict of interest in connection with the manuscript.

Corresponding Author:

Giuseppe Alexandre Romito

E-mail: garomito@usp.br

hitps://doi.org/10.1590/1807-3107bor-2019.vol33.0067

Submitted: June 6, 2019

Accepted for publication: June 11, 2019

Last revision: June 19, 2019
Abstract: Peri-implantitis is currently a topic of major interest in implantology. Considered one of the main reasons of late implant failure, there is an emerged concern whether implant characteristics could trigger inflammatory lesion and loss of supporting bone. The purpose of this narrative review is to provide an evidence based overview on the influence of implant-based factors in the occurrence of peri-implantitis. A literature review was conducted addressing the following topics: implant surface topography; implant location; occlusal overload; time in function; prosthesis-associated factors (rehabilitation extension, excess of cement and implant-abutment connection); and metal particle release. Although existing data suggests that some implant-based factors may increase the risk of peri-implantitis, the evidence is still limited to consider them a true risk factor for peri-implantitis. In conclusion, further evidences are required to a better understanding of the influence of implant-based factors in the occurrence of peri-implantitis. Large population-based studies including concomitant analyses of implant- and patient-based factors are required to provide strong evidence of a possible association with peri-implantitis in a higher probability. The identification of these factors is essential for the establishment of strategies to prevent peri-implantitis.

Keywords: Peri-Implantitis; Dental Implants; Prostheses and Implants; Dental Implant-Abutment Design.

\section{Introduction}

Dental implants have been reported to have high rates of long-term survival, ${ }^{1,2,3,4}$ and hence have become a widely used treatment modality for oral rehabilitation. Therefore, greater emphasis is now placed on understanding the risk factors that may influence the long-term success of osseointegrated implants. Peri-implantitis is considered the major biological complication associated with late implant loss. ${ }^{25,6}$

A myriad of possible risk factors for peri-implantitis could be associated with the dental implant characteristics itself. However, there is a lack of definitive literature corroborating implant-based factors as possible risk for peri-implantitis. Few studies are concentrated in major points related to the implant characteristics. 
Implant surface topography represents one characteristic that could be considered as a possible implant-based risk factor for peri-implantitis. The first modern implants as we know were introduced to the public by P-I Brånermark in 1978, a two-stage threaded machined titanium root-form implant, ${ }^{7}$ being the implant shoulder positioned at the bone level, leading to a submucosal healing, and requiring a further surgical procedure to insert the abutment connection. Few years later, in 1985, Andre Schroeder and the ITI Group introduced the ITI implant system by Straumann Company, with an exclusive plasma-sprayed surface, reducing the time required to achieve osseointegration. ${ }^{8}$ Although it was also a cylindrical implant it was designed to be placed in a one-stage operation with the implant presenting a soft tissue interface, allowing a transmucosal healing. A variety of implants were introduced after the original Brånemark implant, associating or not different modifications based on the initial concept. The tapered form implant, platform switch, different connections like cone morse or hexagons were also developed associated with countless abutments designs. However, it's unclear how these modifications may possible act as risk factors associated with the development or progression of peri-implantitis. Beside these, other implant-based factors that will be also addressed in the present review include: implant location, occlusal overload, time in function, prosthetic factors (rehabilitation extension, excess of cement and implant-abutment connection) and metal particle release. The purpose of this review is to provide an evidenced-based overview on the influence of implant-based factors on the onset and progression of peri-implantitis.

\section{Implant surface topography}

Implant surface topography has a significant effect on the osseointegration and success of titanium implants and encompasses macroscopic, ${ }^{9}$ microscopic and nanometric characteristics. Along with these lines, implant surfaces have been modified over the last decades to enhance the rate and extent of bone formation to achieve more predictable osseointegration. Ultimately, implementation of treated surfaces has been shown to promote increased implant stability during healing, greater bone-to-implant contact, improved long-term treatment outcomes and allowed expanding treatment possibilities in more challenging clinical cases, such as immediate placement and immediate loading. ${ }^{10,11}$

Implant surface modifications have evolved from simple changes of the oxide surface to precise nanoscale modifications capable of modulating critical steps of osseointegration. Following fibrin clot adhesion, blood-derived cells and mesenchymal stem cells interact with implant surfaces in an orchestrated manner that results in bone formation in direct contact with the implant surface. ${ }^{12,13,14}$ In this scenario, implant surface microscopic and nanometric roughness may improve the osseointegration process via several mechanisms. For instance, improvements in surface roughness increase implant surface area, result in formation of a more extensive and complex fibrin scaffold,$^{15}$ increased adhesion, proliferation and osteoblastic differentiation of mesenchymal stem cells and promotes greater matrix mineralization. ${ }^{16}$

Although surface modification was implemented to improve the clinical success of dental implants, the high incidence of complications on first launched rough-surface coated implants let to the hypothesis that these implants could be more prone to peri-implantitis. This initial hypothesis was further strengthened by data showing that rough implants facilitate initial biofilm formation and may impact biofilm composition. ${ }^{17}$ Using bone loss as a surrogate parameter for peri-implantitis, a recent systematic review demonstrated that peri-implant bone loss around minimally rough implants $(0.86 \mathrm{~mm})$ was significantly less than the one around moderately rough $(1.01 \mathrm{~mm})$ and rough implants $(1.04 \mathrm{~mm})$, with no significant differences between moderately rough and rough implant systems. ${ }^{10}$ According to the same study, the prevalence of peri-implant bone loss greater than $2 \mathrm{~mm}$ was higher for implants with rough $(18 \%)$ and moderately rough surfaces $(20 \%)$ than for implants with minimally rough surfaces (14\%).

Implants with acid-etched surfaces showed high survival and success rates after 8-10 years of function in a retrospective study. Forty-four patients who received 183 implants were evaluated. Only 5 implants were lost during this period (2.7\%) and 20 implants were diagnosis with peri-implantitis $(11 \%){ }^{18}$ 
It is important to highlight that most studies evaluating the impact of implant surface characteristics on the development and/or progression of peri-implantitis, compared implants differing in their design and prosthetic connection. Only three retrospective studies have compared the incidence of marginal bone loss and peri-implant disease in implants differing in surface topography, but with equal design. ${ }^{19,20,21}$ Altogether, a meta-analysis of these three studies revealed that minimally rough implants have less bone loss than moderately rough implants. ${ }^{10}$

In conclusion, although existing data suggests that rough and moderately rough implants might have a higher risk to peri-implantitis, well designed long-term prospective clinical trials are needed to validate or refute these findings.

\section{Implant Location}

Considerable cross-sectional studies have reported on a correlation between implant site (maxilla/mandible or anterior/posterior) and the prevalence or risk factor for peri-implant diseases. Employing a variety of statistical analysis, different inclusion and exclusion criteria, and disease definition, implant maxillary sites were suggested as statistically significant risk indicators, ${ }^{22,23,24,25}$ while controversial data is also available. ${ }^{26,27,28,29}$ For peri-implantitis, even when significant association with location is identified, there is still questionable evidence whether upper jaw $^{22,23,24,26}$ is considered the most prevalent region for peri-implantitis or lower jaw, ${ }^{25}$ as well as anterior ${ }^{24,26}$ and posterior sites. ${ }^{27,29,30} \mathrm{In}$ fact, bone component is denser in mandibles and anterior areas and osseous volume tends to become thinner and more porous directly proportional to age. This correlation is most likely related to the bone quality, difficult access to perform oral hygiene, and occlusal load, intrinsic to the different regions of the oral cavity.

Peri-implant health is rather more associated to the periodontal condition of the remaining teeth close to the dental implant than to implant location in the jaw. Recently, the periodontal status of the adjacent and contralateral teeth to the implants with and without peri-implantitis was compared ${ }^{31}$ The results suggested that the peri-implant health status is associated to the health periodontal condition of the tooth adjacent to the implant. Correspondingly, the presence of peri-implantitis affected the periodontal measurements of the tooth adjacent to these involved implants. ${ }^{31}$ Furthermore, a cross-sectional study demonstrated that implant placement at a depth of $6 \mathrm{~mm}$ or more from the cement-enamel junction of the adjacent tooth was a strong predictor for peri-implantitis (OR 8.5) as well as the presence of gingivitis and periodontitis on the adjoining teeth at the time of implant restoration (OR 8.0). ${ }^{32}$

There is currently no conclusive evidence that implant location constitutes a risk indicator for the onset or progression of peri-implantitis.

\section{Occlusal overload}

Peri-implant tissues facing overload damage and plaque-induced inflammation present different histological features, where minimal inflammatory infiltrate is observed on the first. For this reason, a specific histopathogenic mechanism associated to overload implants has been suggested. ${ }^{33,34,35,36}$ Defining whether an implant is under excessive load or not is crucial to consider it as a risk factor/indicator for peri-implantitis. There is a lack of consensual parameters to standardize these investigations for the pathway of overload integrated implants. ${ }^{37}$ In a classic study in dogs, it was demonstrated that lateral static load with controlled forces does not increase the risk for peri-implant marginal bone loss. ${ }^{38}$ This conclusion has been expanded for occlusal load in latter investigations. ${ }^{36,39,40,41,42}$ Occlusal load, when controlled and associated with implants with no biofilm accumulation results in increased bone density and bone-implant contact, but in the presence of plaque, it may contribute to bone loss. ${ }^{39,40,42,43}$ Several clinical studies have also reported a relationship between overload and bone loss around dental implants, ${ }^{44,45,46,47,48,49}$ but most of these studies highlighted the presence of microorganisms as the key causative factor or did not investigate a possible correlation with poor oral hygiene, the occurrence of parafunctional habits, and other factors related to prostheses.

Clinical signs of occlusal overload, such as abutment fracture, loss of retention, chipping and dynamic occlusal measurements, were observed in a higher frequency at peri-implantitis sites 
(27 out of 98 implants) than in healthy peri-implant condition (3 out of 204 implants), with an OR of 18.7.50 In addition, the presence of wear facets on the implant supported crowns was associated with peri-implantitis (OR 2.4). ${ }^{26}$ Although these previous data have suggested a relationship between occlusal overload and peri-implantitis, further evidences are required to confirm the occlusal influence in the onset and progression of peri-implantitis. In a recent cross-sectional study, the association of occlusal interference with peri-implantitis was not significant after adjustment for other patient and implant-level variables included in the multivariate analysis. ${ }^{51}$

\section{Time in function}

Time in function as a risk factor for peri-implantitis is also a controversial issue in the literature. Previous cross-sectional studies indicated that time in function is associated with the occurrence of peri-implantitis. $51,52,53,54$ The percentage of peri-implantitis was higher in individuals with implants with more than 10 years in function $(38.4 \%)$ than in those with lower time in function (17.6\%). ${ }^{53}$ In addition, a significant positive correlation was observed between peri-implantitis and time of loading, ${ }^{52}$ and the probability of peri-implantitis was two times higher for implants loaded for 5 years or more. ${ }^{51}$ On the other hand, other studies reported no association between implant time in function and peri-implantitis. $22,55,56$

The effectiveness of implant therapy was evaluated in a Swedish population. It was verified that early implant loss occurred in $4.4 \%$ of patients and $1.4 \%$ of implants, while $4.2 \%$ of the patients and $2.0 \%$ of the implants presented with late implant loss after around 9 years of loading. In this study, the loss of dental implants was assessed in a large and randomly selected patient sample (early loss: 2,765 patients and 11,311 implants; late loss: 596 patients and 2,367 implants). ${ }^{57}$

In fact, peri-implantitis could be considered a time-dependent condition, but there is no evidence to support a cause-and-effect relationship.

\section{Prosthesis-associated factors}

According to the literature, among all prosthesis-associated factors considered possible risk indicators for peri-implantitis only three are considered relevant, including: prosthetic rehabilitation extension, ${ }^{26,58}$ excess of cement, ${ }^{59,60,60,61,62,63,64,65,66,67,68,69,70,71}$ and implant-abutment connection type. $72,73,74,75,76,77,78,79,80,81,82,83$

\section{Prosthetic rehabilitation extension}

Studies have demonstrated that implants supporting fixed bridges, removable superstructures or total rehabilitation displayed a higher risk for peri-implant disease. ${ }^{26,58}$ The difficulty to perform adequate oral hygiene around implants supporting these types of prosthetic rehabilitation is likely to justify the higher occurrence of peri-implantitis. Furthermore, it is important to highlight that full-mouth rehabilitations are likely related to patients with previous experience of periodontal disease, while single crown rehabilitations are usually alternative treatments for root fractures or endodontic failures.

\section{Excess of cement}

Although using a variety of different case definitions, observational studies found a positive relationship between the presence of excess cement and the occurrence of mucositis and peri-implantitis. 59,60,61,62,63 This association may be explained by the rough surface of the residual cement that facilitate microorganism retention and biofilm formation. ${ }^{62,64}$ However, a considerable variation can be observed among the studies on the percentage of diseased implant sites exhibiting excess cement ${ }^{59,60,61,62,63}$ and several studies did not find higher occurrence of peri-implantitis in cement-retained implant-supported restorations than in screw-retained restorations ${ }^{51,52,57,65,66}$. Furthermore, the mode of retention of implant-supported crowns does not appear to affect clinical and immune- inflammatory parameters. ${ }^{65,67}$

The excess cement appears to have influence of the cementation margin level, the deeper the subgingival interface implant-abutment, the greater amount of undetected cement was discovered. ${ }^{63,68}$ Authors have suggested that cements containing zinc may lead to fewer negative tissue reactions, ${ }^{70,69}$ apparently zinc-based cements demonstrate the highest solubility when compared to other types. ${ }^{70}$ A recent systematic review recommends the use of zinc oxide eugenol cements in patients with a history of periodontitis instead of resin cements. ${ }^{71}$ 
The excess cement may be considered an iatrogenic factor that may influence the onset and progression of peri-implantitis. The signs and symptoms of inflammation recede after removal of excess cement. ${ }^{60,61,62}$ Then, with appropriate cement selection and detailed attention to removal excess of cement, cemented-retained restorations are not a risk indicator for peri-implantitis. ${ }^{66}$

\section{Type of implant-abutment connection}

Several studies have reported that platform switching system is associated with reduced marginal bone loss around implants. $72,73,74,75,76,77,78$ The crestal bone stability is justified by the inward shifting of the implant-abutment junction that transfers the peri-implant microbiota and the inflammatory cell infiltrate away from the adjacent crestal bone and creates a space for biologic width formation. ${ }^{79,80,81} \mathrm{In}$ addition, platform switching decreases the forces concentration in the crestal bone-implant interface during occlusal loading. ${ }^{82}$ However, scarce information is available in the literature concerning the impact of different platform designs on peri-implant diseases. In a cross-sectional study with a small sample size (25 patients and 64 implants), the prevalence of mucositis and peri-implantitis after one year of loading for platform switching was $90 \%$ and $15.6 \%$, respectively, and $81.2 \%$ and $15.6 \%$ for conventional implants. These differences were not statistically significant. ${ }^{83}$ Recently, it was verified that implants with platform switching have $82 \%$ lower probability of developing peri-implantitis than conventionally restored implants. ${ }^{51}$

In conclusion, further evidences are required to confirm the previously discussed prosthesis-associated factors as risk/indicator factors for peri-implantitis.

\section{Metal particle release}

In the field of medicine, primarily in orthopedics, metal particles release has been intensively studied as a potential risk factor for implants failure. ${ }^{84,85,86,87}$ Correspondingly, in implant dentistry, titanium particles dispersed in adjacent tissue of implants are also considered foreign bodies and may provoke negative effects..$^{88}$ Independent studies have detected the presence of metal particles in soft tissue samples from peri-implantitis sites. ${ }^{88,89,90,91,92,93,94}$ Although investigations might not confirm the relationship between titanium content within tissue and peri-implant inflammation, these findings may have a significant importance since several studies have reported negative effects of implant debris on cells and tissue. ${ }^{91,95,96,97,98,99,100,101,102}$ Recent studies suggested the stimulation of osteoclast activity and exacerbated proinflammatory response in the presence of titanium-based particles and ions. ${ }^{91,98}$ Researchers also detected genotoxic and cytotoxic potential of nanometric metal particles, ${ }^{99,101}$ and their ability to produce morphological changes in neutrophils and macrophages and activate DNA damage response in oral epithelial cells. ${ }^{102,103}$ However, there is not sufficient evidence to support whether metal content has a significant impact or not in the immune response. ${ }^{104,105}$

Adversely to orthopedic prosthesis, which are placed in a closed site, dental implants are exposed to many intrinsic factors related to the oral cavity. Plausible causes for metal particle release are related to mechanical and chemical principles: wear particles generated during implant placement surgery; ${ }^{106}$ implant-abutment connection under force transmission; ${ }^{107,108,109}$ and tribocorrosion, this last is a result of the combined effect of wear (micromotion) and corrosion substances present in the oral cavity (e.g., lactic acid, fluoride, citric acid). ${ }^{110,111,112}$ The mechanism responsible for metal particles and ions release remains unclear, just as the possible local impact of that content on implant-associated tissue. ${ }^{113,114}$ At this moment, the available evidence does not allow an assessment of metal particles as a risk factor for peri-implantitis.

\section{Conclusion}

Further evidences are required to a better understanding of the influence of implant-based factors in the occurrence of peri-implantitis. In fact, large population-based studies including concomitant analyses of implant- and patient-based factors are required to identify the factors significantly associated with higher probability of peri-implantitis. The identification of these factors is essential for the establishment of strategies to prevent peri-implantitis and for the effective prognostic of dental implants success. 


\section{References}

1. Lambrecht JT, Filippi A, Künzel AR, Schiel HJ. Long-term evaluation of submerged and nonsubmerged ITI solid-screw titanium implants: a 10 -year life table analysis of 468 implants. Int J Oral Maxillofac Implants. 2003 Nov-Dec;18(6):826-34. https://doi.org/10.1016/i.prosdent.2004.03.019

2. Roos-Jansåker AM, Lindahl C, Renvert H, Renvert S. Nine- to fourteen-year follow-up of implant treatment. Part I: implant loss and associations to various factors. J Clin Periodontol. 2006 Apr;33(4):283-9. https://doi.org/10.1111/i.1600-051X.2006.00907.x

3. Buser D, Janner SF, Wittneben JG, Brägger U, Ramseier CA, Salvi GE. 10-year survival and success rates of 511 titanium implants with a sandblasted and acid-etched surface: a retrospective study in 303 partially edentulous patients. Clin Implant Dent Relat Res. 2012 Dec;14(6):839-51. https://doi.org/10.1111/j.1708-8208.2012.00456.x

4. Velzen FJ, Ofec R, Schulten EA, Ten Bruggenkate CM. 10-year survival rate and the incidence of peri-implant disease of 374 titanium dental implants with a SLA surface: a prospective cohort study in 177 fully and partially edentulous patients. Clin Oral Implants Res. 2015 Oct;26(10):1121-8. https://doi.org/10.1111/clr.12499

5. Fransson C, Lekholm U, Jemt T, Berglundh T. Prevalence of subjects with progressive bone loss at implants. Clin Oral Implants Res. 2005 Aug;16(4):440-6. https://doi.org/10.1111/j.1600-0501.2005.01137.x

6. Karoussis IK, Salvi GE, Heitz-Mayfield LJ, Brägger U, Hämmerle CH, Lang NP. Long-term implant prognosis in patients with and without a history of chronic periodontitis: a 10-year prospective cohort study of the ITI Dental Implant System. Clin Oral Implants Res. 2003 Jun;14(3):329-39. https://doi.org/10.1034/j.1600-0501.000.00934.x

7. Brånemark PI, Zarb GA, Albrektsson T. Tissue-integrated prostheses: osseointegration in clinical dentistry. Chicago: Quintessence; 1985.

8. Laney WR. In recognition of an implant pioneer: Professor Dr. André Schroeder. Int J Oral Maxillofac Implants. 1993;8(2):135-6.

9. Le Guéhennec L, Soueidan A, Layrolle P, Amouriq Y. Surface treatments of titanium dental implants for rapid osseointegration. Dent Mater. 2007 Jul;23(7):844-54. https://doi.org/10.1016/i.dental.2006.06.025

10. Doornewaard R, Christiaens V, De Bruyn H, Jacobsson M, Cosyn J, Vervaeke S, et al. Long-term effect of surface roughness and patients' factors on crestal bone loss at dental implants. A systematic review and meta-analysis. Clin Implant Dent Relat Res. 2017 Apr;19(2):372-99. https://doi.org/10.1111/cid.12457

11. De Bruyn H, Christiaens V, Doornewaard R, Jacobsson M, Cosyn J, Jacquet W, et al. Implant surface roughness and patient factors on long-term peri-implant bone loss. Periodontol 2000. 2017 Feb;73(1):218-27. https://doi.org/10.1111/prd.12177

12. Meyer U, Joos U, Mythili J, Stamm T, Hohoff A, Fillies T, et al. Ultrastructural characterization of the implant/bone interface of immediately loaded dental implants. Biomaterials. 2004 May;25(10):1959-67. https://doi.org/10.1016/j.biomaterials.2003.08.070

13. Berglundh T, Abrahamsson I, Lang NP, Lindhe J. De novo alveolar bone formation adjacent to endosseous implants. Clin Oral Implants Res. 2003 Jun;14(3):251-62. https://doi.org/10.1034/j.1600-0501.2003.00972.x

14. Masuda T, Salvi GE, Offenbacher S, Felton DA, Cooper LF. Cell and matrix reactions at titanium implants in surgically prepared rat tibiae. Int J Oral Maxillofac Implants. 1997 Jul-Aug;12(4):472-85.

15. Di lorio D, Traini T, Degidi M, Caputi S, Neugebauer J, Piattelli A. Quantitative evaluation of the fibrin clot extension on different implant surfaces: an in vitro study. J Biomed Mater Res B Appl Biomater. 2005 Jul;74(1):636-42. https://doi.org/10.1002/jbm.b.30251

16. Olivares-Navarrete R, Hyzy SL, Park JH, Dunn GR, Haithcock DA, Wasilewski CE, et al. Mediation of osteogenic differentiation of human mesenchymal stem cells on titanium surfaces by a Wnt-integrin feedback loop. Biomaterials. 2011 Sep;32(27):6399-411. https://doi.org/10.1016/i.biomaterials.2011.05.036

17. Teughels W, Van Assche N, Sliepen I, Quirynen M. Effect of material characteristics and/or surface topography on biofilm development. Clin Oral Implants Res. 2006 Oct;17(S2 Suppl 2):68-81. https://doi.org/10.1111/j.1600-0501.2006.01353.x

18. Nicoli LG, Oliveira GJ, Lopes BM, Marcantonio C, Zandim-Barcelos DL, Marcantonio E Jr. Survival/success of dental implants with acid-etched surfaces: A retrospective evaluation after 8 to 10 years. Braz Dent J. 2017 May-Jun;28(3):330-6. https://doi.org/10.1590/0103-6440201601471

19. Vandeweghe S, Ferreira D, Vermeersch L, Mariën M, De Bruyn H. Long-term retrospective follow-up of turned and moderately rough implants in the edentulous jaw. Clin Oral Implants Res. 2016 Apr;27(4):421-6. https://doi.org/10.1111/clr.12602

20. Jungner $M$, Lundqvist $P$, Lundgren $S$. A retrospective comparison of oxidized and turned implants with respect to implant survival, marginal bone level and peri-implant soft tissue conditions after at least 5 years in function. Clin Implant Dent Relat Res. 2014 Apr;16(2):230-7. https://doi.org/10.1111/j.1708-8208.2012.00473.x

21. Sayardoust S, Gröndahl K, Johansson E, Thomsen P, Slotte C. Implant survival and marginal bone loss at turned and oxidized implants in periodontitis-susceptible smokers and never-smokers: a retrospective, clinical, radiographic case-control study. J Periodontol. 2013 Dec;84(12):1775-82. https://doi.org/10.1902/jop.2013.120608

22. Koldsland $O C$, Scheie AA, Aass AM. The association between selected risk indicators and severity of peri-implantitis using mixed model analyses. J Clin Periodontol. 2011 Mar;38(3):285-92. https://doi.org/10.1111/j.1600-051X.2010.01659.x

23. Konstantinidis IK, Kotsakis GA, Gerdes S, Walter MH. Cross-sectional study on the prevalence and risk indicators of peri-implant diseases. Eur J Oral Implantol. 2015;8(1):75-88. 
24. Serino G, Turri A. Extent and location of bone loss at dental implants in patients with peri-implantitis. J Biomech. 2011 Jan;44(2):267-71. https://doi.org/10.1016/i.jbiomech.2010.10.014

25. Aguirre-Zorzano LA, Estefanía-Fresco R, Telletxea O, Bravo M. Prevalence of peri-implant inflammatory disease in patients with a history of periodontal disease who receive supportive periodontal therapy. Clin Oral Implants Res. 2015 Nov;26(11):1338-44. https://doi.org/10.1111/clr.12462

26. Dalago HR, Schuldt Filho G, Rodrigues MA, Renvert S, Bianchini MA. Risk indicators for Peri-implantitis. A cross-sectional study with 916 implants. Clin Oral Implants Res. 2017 Feb;28(2):144-50. https://doi.org/10.1111/clr.12772

27. Dvorak G, Arnhart C, Heuberer S, Huber CD, Watzek G, Gruber R. Peri-implantitis and late implant failures in postmenopausal women: a cross-sectional study. J Clin Periodontol. 2011 Oct;38(10):950-5. https://doi.org/10.1111/j.1600-051X.2011.01772.x

28. Nobre AM, Maló PS, Oliveira SH. The influence of implant location and position characteristics on peri-implant pathology. Eur J Prosthodont Restor Dent. 2014 Sep;22(3):125-9.

29. Rammelsberg P, Lorenzo-Bermejo J, Kappel S. Effect of prosthetic restoration on implant survival and success. Clin Oral Implants Res. 2017 Oct;28(10):1296-302. https://doi.org/10.1111/clr.12974

30. Ferreira CF, Buttendorf AR, de Souza JG, Dalago H, Guenther SF, Bianchini MA. Prevalence of peri-implant diseases: analyses of associated factors. Eur J Prosthodont Restor Dent. 2015 Dec;23(4):199-206.

31. Sung CE, Chiang CY, Chiu HC, Shieh YS, Lin FG, Fu E. Periodontal status of tooth adjacent to implant with peri-implantitis. J Dent. 2018 Mar;70:104-9. https://doi.org/10.1016/i.jdent.2018.01.004

32. Kumar PS, Dabdoub SM, Hegde R, Ranganathan N, Mariotti A. Site-level risk predictors of peri-implantitis: A retrospective analysis. J Clin Periodontol. 2018 May;45(5):597-604. https://doi.org/10.1111/jcpe.12892

33. Isidor F. Histological evaluation of peri-implant bone at implants subjected to occlusal overload or plaque accumulation. Clin Oral Implants Res. 1997 Feb;8(1):1-9. https://doi.org/10.1111/j.1600-0501.1997.tb00001.x

34. Nagasawa M, Takano R, Maeda T, Uoshima K. Observation of the bone surrounding an overloaded implant in a novel rat model. Int J Oral Maxillofac Implants. 2013 Jan-Feb;28(1):109-16. https://doi.org/10.11607/jomi.2388

35. Miyata T, Kobayashi Y, Araki H, Ohto T, Shin K. The influence of controlled occlusal overload on peri-implant tissue. Part 3: A histologic study in monkeys. Int J Oral Maxillofac Implants. 2000 May-Jun;15(3):425-31.

36. Pellegrini G, Canullo L, Dellavia C. Histological features of peri-implant bone subjected to overload. Ann Anat. 2016 Jul;206:57-63. https://doi.org/10.1016/i.aanat.2015.02.011

37. Afrashtehfar KI, Afrashtehfar CD. Lack of association between overload and peri-implant tissue loss in healthy conditions. Evid Based Dent. 2016 Sep;17(3):92-3. https://doi.org/10.1038/sj.ebd.6401193

38. Gotfredsen K, Berglundh T, Lindhe J. Bone reactions at implants subjected to experimental peri-implantitis and static load: a study in the dog. J Clin Periodontol. 2002 Feb;29(2):144-51. https://doi.org/10.1034/j.1600-051x.2002.290209.x

39. Heitz-Mayfield LJ, Schmid B, Weigel C, Gerber S, Bosshardt DD, Jönsson J, et al. Does excessive occlusal load affect osseointegration? An experimental study in the dog. Clin Oral Implants Res. 2004 Jun;15(3):259-68. https://doi.org/10.1111/j.1600-0501.2004.01019.x

40. Kozlovsky A, Tal H, Laufer BZ, Leshem R, Rohrer MD, Weinreb M, et al. Impact of implant overloading on the peri-implant bone in inflamed and non-inflamed peri-implant mucosa. Clin Oral Implants Res. 2007 Oct;18(5):601-10. https://doi.org/10.1111/j.1600-0501.2007.01374.x

41. Lee DW, Lee DW, Park KH, Moon IS. The effects of off-axial loading on periimplant marginal bone loss in a single implant. J Prosthet Dent. 2014 Sep;112(3):501-7. https://doi.org/10.1016/i.prosdent.2014.02.004

42. Naert I, Duyck J, Vandamme K. Occlusal overload and bone/implant loss. Clin Oral Implants Res. 2012 Oct;23 Suppl 6:95-107. https://doi.org/10.1111/j.1600-0501.2012.02550.x

43. Chambrone L, Chambrone LA, Lima LA. Effects of occlusal overload on peri-implant tissue health: a systematic review of animal-model studies. J Periodontol. 2010 Oct;81(10):1367-78. https://doi.org/10.1902/jop.2010.100176

44. Lindquist LW, Rockler B, Carlsson GE. Bone resorption around fixtures in edentulous patients treated with mandibular fixed tissue-integrated prostheses. J Prosthet Dent. 1988 Jan;59(1):59-63. https://doi.org/10.1016/0022-3913(88)90109-6

45. Quirynen M, Naert I, van Steenberghe D. Fixture design and overload influence marginal bone loss and fixture success in the Brånemark system. Clin Oral Implants Res. 1992 Sep;3(3):104-11. https://doi.org/10.1034/i.1600-0501.1992.030302.x

46. Rangert B, Krogh PH, Langer B, Van Roekel N. Bending overload and implant fracture: a retrospective clinical analysis. Int J Oral Maxillofac Implants. 1995 May-Jun;10(3):326-34.

47. Lindquist LW, Carlsson GE, Jemt T. A prospective 15-year follow-up study of mandibular fixed prostheses supported by osseointegrated implants: clinical results and marginal bone loss. Clin Oral Implants Res. 1996 Dec;7(4):329-36. https://doi.org/10.1034/j.1600-0501.1996.070405.x

48. Esposito M, Thomsen P, Ericson LE, Sennerby L, Lekholm U. Histopathologic observations on late oral implant failures. Clin Implant Dent Relat Res. 2000;2(1):18-32. https://doi.org/10.1111/j.1708-8208.2000.tb00103.x

49. Heckmann SM, Linke JJ, Graef F, Foitzik C, Wichmann MG, Weber HP. Stress and inflammation as a detrimental combination for peri-implant bone loss. J Dent Res. 2006 Aug;85(8):711-6. https://doi.org/10.1177/154405910608500805 
50. Canullo L, Tallarico M, Radovanovic S, Delibasic B, Covani U, Rakic M. Distinguishing predictive profiles for patient-based risk assessment and diagnostics of plaque induced, surgically and prosthetically triggered peri-implantitis. Clin Oral Implants Res. 2016 Oct;27(10):1243-50. https://doi.org/10.1111/clr.12738

51. Pimentel SP, Shiota R, Cirano FR, Casarin RC, Pecorari VG, Casati MZ, et al. Occurrence of peri-implant diseases and risk indicators at the patient and implant levels: A multilevel cross-sectional study. J Periodontol. 2018 Sep;89(9):1091-100. https://doi.org/10.1002/JPER.17-0599

52. Máximo MB, de Mendonça AC, Alves JF, Cortelli SC, Peruzzo DC, Duarte PM. Peri-implant diseases may be associated with increased time loading and generalized periodontal bone loss: preliminary results. J Oral Implantol. 2008;34(5):268-73. https://doi.org/10.1563/1548-1336(2008)34[269:PDMBAW]2.0.CO;2

53. Marrone A, Lasserre J, Bercy P, Brecx MC. Prevalence and risk factors for peri-implant disease in Belgian adults. Clin Oral Implants Res. 2013 Aug;24(8):934-40. https://doi.org/10.1111/j.1600-0501.2012.02476.x

54. Lee CT, Huang YW, Zhu L, Weltman R. Prevalences of peri-implantitis and peri-implant mucositis: systematic review and meta-analysis. $J$ Dent. 2017 Jul;62:1-12. https://doi.org/10.1016/i.jdent.2017.04.011

55. Ferreira SD, Silva GL, Cortelli JR, Costa JE, Costa FO. Prevalence and risk variables for peri-implant disease in Brazilian subjects. J Clin Periodontol. 2006 Dec;33(12):929-35. https://doi.org/10.1111/j.1600-051X.2006.01001.x

56. Sánchez-Siles M, Muñoz-Cámara D, Salazar-Sánchez N, Ballester-Ferrandis JF, Camacho-Alonso F. Incidence of peri-implantitis and oral quality of life in patients rehabilitated with implants with different neck designs: A 10-year retrospective study. J Craniomaxillofac Surg. 2015 Dec;43(10):2168-74. https://doi.org/10.1016/i.jcms.2015.10.010

57. Derks J, Håkansson J, Wennström JL, Tomasi C, Larsson M, Berglundh T. Effectiveness of implant therapy analyzed in a Swedish population: early and late implant loss. J Dent Res. 2015 Mar;94(3 Suppl):44S-51S. https://doi.org/10.1177/0022034514563077

58. Swierkot K, Lottholz P, Flores-de-Jacoby L, Mengel R. Mucositis, peri-implantitis, implant success, and survival of implants in patients with treated generalized aggressive periodontitis: 3- to 16-year results of a prospective long-term cohort study. J Periodontol. 2012 Oct;83(10):1213-25. https://doi.org/10.1902/jop.2012.110603

59. Korsch M, Obst U, Walther W. Cement-associated peri-implantitis: a retrospective clinical observational study of fixed implant-supported restorations using a methacrylate cement. Clin Oral Implants Res. 2014 Jul;25(7):797-802. https://doi.org/10.1111/clr.12173

60. Korsch M, Walther W. Peri-implantitis associated with type of cement: A retrospective analysis of different types of cement and their clinical correlation to the peri-implant tissue. Clin Implant Dent Relat Res. 2015 Oct;17 Suppl 2:e434-43. https://doi.org/10.1111/cid.12265

61. Korsch M, Walther W, Bartols A. Cement-associated peri-implant mucositis. A 1-year follow-up after excess cement removal on the peri-implant tissue of dental implants. Clin Implant Dent Relat Res. 2017 Jun;19(3):523-9. https://doi.org/10.1111/cid.12470

62. Wilson TG Jr. The positive relationship between excess cement and peri-implant disease: a prospective clinical endoscopic study. J Periodontol. 2009 Sep;80(9):1388-92. https://doi.org/10.1902/jop.2009.090115

63. Linkevicius T, Vindasiute E, Puisys A, Linkeviciene L, Maslova N, Puriene A. The influence of the cementation margin position on the amount of undetected cement. A prospective clinical study. Clin Oral Implants Res. 2013 Jan;24(1):71-6. https://doi.org/10.1111/j.1600-0501.2012.02453.x

64. Staubli N, Walter C, Schmidt JC, Weiger R, Zitzmann NU. Excess cement and the risk of peri-implant disease - a systematic review. Clin Oral Implants Res. 2017 Oct;28(10):1278-90. https://doi.org/10.1111/clr.12954

65. Daubert DM, Weinstein BF, Bordin S, Leroux BG, Flemming TF. Prevalence and predictive factors for peri-implant disease and implant failure: a cross-sectional analysis. J Periodontol. 2015 Mar;86(3):337-47. https://doi.org/10.1902/jop.2014.140438

66. Kotsakis GA, Zhang L, Gaillard P, Raedel M, Walter MH, Konstantinidis IK. Investigation of the association between cement retention and prevalent peri-implant diseases: a cross-sectional study. J Periodontol. 2016 Mar;87(3):212-20. https://doi.org/10.1902/jop.2015.150450

67. Al Amri MD, Al-Rasheed AS, Al-Kheraif AA, Alfadda SA. Comparison of clinical, radiographic, and immunologic inflammatory parameters around dental implants with cement-retained and screw-retained restorations: A 5-year prospective cohort study in men. Int J Prosthodont. 2017 Jul/Aug;30(4):384-9. https://doi.org/10.11607/ijp.5078

68. Linkevicius T, Vindasiute E, Puisys A, Peciuliene V. The influence of margin location on the amount of undetected cement excess after delivery of cement-retained implant restorations. Clin Oral Implants Res. 2011 Dec;22(12):1379-84. https://doi.org/10.1111/j.1600-0501.2010.02119.x

69. Rodriguez LC, Saba JN, Chung KH, Wadhwani C, Rodrigues DC. In vitro effects of dental cements on hard and soft tissues associated with dental implants. J Prosthet Dent. 2017 Jul;118(1):31-5. https://doi.org/10.1016/i.prosdent.2016.10.002

70. Yanikoğlu N, Yeşil Duymuş Z. Evaluation of the solubility of dental cements in artificial saliva of different pH values. Dent Mater J. 2007 Jan;26(1):62-7. https://doi.org/10.4012/dmj.26.62

71. Quaranta A, Lim ZW, Tang J, Perrotti V, Leichter J. The impact of residual subgingival cement on biological complications around dental implants: A systematic review. Implant Dent. 2017 Jun;26(3):465-74. https://doi.org/10.1097/ID.0000000000000593

72. Gardner DM. Platform switching as a means to achieving implant esthetics. N Y State Dent J. 2005 Apr;71(3):34-7.

73. Baumgarten H, Cocchetto R, Testori T, Meltzer A, Porter S. A new implant design for crestal bone preservation: initial observations and case report. Pract Proced Aesthet Dent. 2005 Nov-Dec;17(10):735-40.

74. Lazzara RJ, Porter SS. Platform switching: a new concept in implant dentistry for controlling postrestorative crestal bone levels. Int J Periodontics Restorative Dent. 2006 Feb;26(1):9-17. 
75. Vigolo P, Givani A. Platform-switched restorations on wide-diameter implants: a 5-year clinical prospective study. Int J Oral Maxillofac Implants. 2009 Jan-Feb;24(1):103-9.

76. Rocha S, Wagner W, Wiltfang J, Nicolau P, Moergel M, Messias A, et al. Effect of platform switching on crestal bone levels around implants in the posterior mandible: 3 years results from a multicentre randomized clinical trial. J Clin Periodontol. 2016 Apr;43(4):374-82. https://doi.org/10.1111/icpe.12522

77. Moergel M, Rocha S, Messias A, Nicolau P, Guerra F, Wagner W. Radiographic evaluation of conical tapered platform-switched implants in the posterior mandible: 1-year results of a two-center prospective study. Clin Oral Implants Res. 2016 Jun;27(6):686-93. https://doi.org/10.1111/clr.12644

78. Guerra F, Wagner W, Wiltfang J, Rocha S, Moergel M, Behrens E, et al. Platform switch versus platform match in the posterior mandible - 1-year results of a multicentre randomized clinical trial. J Clin Periodontol. 2014 May;41(5):521-9. https://doi.org/10.1111/icpe.12244

79. Broggini N, McManus LM, Hermann JS, Medina R, Schenk RK, Buser D, et al. Peri-implant inflammation defined by the implant-abutment interface. J Dent Res. 2006 May;85(5):473-8. https://doi.org/10.1177/154405910608500515

80. Cochran DL, Bosshardt DD, Grize L, Higginbottom FL, Jones AA, Jung RE, et al. Bone response to loaded implants with non-matching implant-abutment diameters in the canine mandible. J Periodontol. 2009 Apr;80(4):609-17. https://doi.org/10.1902/jop.2009.080323

81. Canullo L, Fedele GR, lannello G, Jepsen S. Platform switching and marginal bone-level alterations: the results of a randomized-controlled trial. Clin Oral Implants Res. 2010 Jan;21(1):115-21. https://doi.org/10.1111/j.1600-0501.2009.01867.x

82. Maeda Y, Miura J, Taki I, Sogo M. Biomechanical analysis on platform switching: is there any biomechanical rationale? Clin Oral Implants Res. 2007 Oct;18(5):581-4. https://doi.org/10.1111/j.1600-0501.2007.01398.x

83. Duque AD, Aristizabal AG, Londoño S, Castro L, Alvarez LG. Prevalence of peri-implant disease on platform switching implants: a cross-sectional pilot study. Braz Oral Res. 2016;30(1):S1806-83242016000100204. https://doi.org/10.1590/1807-3107BOR-2016.vol30.0005

84. Dorr LD, Bloebaum R, Emmanual J, Meldrum R. Histologic, biochemical, and ion analysis of tissue and fluids retrieved during total hip arthroplasty. Clin Orthop Relat Res. 1990 Dec;\&NA;(261):82-95. https://doi.org/10.1097/00003086-199012000-00010

85. Martini D, Fini M, Franchi M, Pasquale VD, Bacchelli B, Gamberini M, et al. Detachment of titanium and fluorohydroxyapatite particles in unloaded endosseous implants. Biomaterials. 2003 Mar;24(7):1309-16. https://doi.org/10.1016/S0142-9612(02)00508-2

86. Urban RM, Jacobs JJ, Tomlinson MJ, Gavrilovic J, Black J, Peoc'h M. Dissemination of wear particles to the liver, spleen, and abdominal lymph nodes of patients with hip or knee replacement. J Bone Joint Surg Am. 2000 Apr;82(4):457-76. https://doi.org/10.2106/00004623-200004000-00002

87. Woodman JL, Jacobs JJ, Galante JO, Urban RM. Metal ion release from titanium-based prosthetic segmental replacements of long bones in baboons: a long-term study. J Orthop Res. 1984;1(4):421-30. https://doi.org/10.1002/jor.1100010411

88. Wilson TG Jr, Valderrama P, Burbano M, Blansett J, Levine R, Kessler H, et al. Foreign bodies associated with peri-implantitis human biopsies. J Periodontol. 2015 Jan;86(1):9-15. https://doi.org/10.1902/jop.2014.140363

89. Fretwurst T, Buzanich G, Nahles S, Woelber JP, Riesemeier H, Nelson K. Metal elements in tissue with dental peri-implantitis: a pilot study. Clin Oral Implants Res. 2016 Sep;27(9):1178-86. https://doi.org/10.1111/clr.12718PMID:26508041

90. Olmedo DG, Nalli G, Verdú S, Paparella ML, Cabrini RL. Exfoliative cytology and titanium dental implants: a pilot study. J Periodontol. 2013 Jan;84(1):78-83. https://doi.org/10.1902/jop.2012.110757

91. Pettersson M, Kelk P, Belibasakis GN, Bylund D, Molin Thorén M, Johansson A. Titanium ions form particles that activate and execute interleukin-1 $\beta$ release from lipopolysaccharide-primed macrophages. J Periodontal Res. 2017 Feb;52(1):21-32. https://doi.org/10.1111/ire.12364

92. Schwarz F, Sahm N, Mihatovic I, Golubovic V, Becker J. Surgical therapy of advanced ligature-induced peri-implantitis defects: cone-beam computed tomographic and histological analysis. J Clin Periodontol. 2011 Oct;38(10):939-49. https://doi.org/10.1111/j.1600-051X.2011.01739.x

93. Meyer U, Bühner M, Büchter A, Kruse-Lösler B, Stamm T, Wiesmann HP. Fast element mapping of titanium wear around implants of different surface structures. Clin Oral Implants Res. 2006 Apr;17(2):206-11. https://doi.org/10.1111/j.1600-0501.2005.01184.x

94. Penmetsa SL, Shah R, Thomas R, Kumar AB, Gayatri PS, Mehta DS. Titanium particles in tissues from peri-implant mucositis: an exfoliative cytology-based pilot study. J Indian Soc Periodontol. 2017 May-Jun;21(3):192-4. https://doi.org/10.4103/jisp.jisp_184_16

95. Goodman SB. Wear particles, periprosthetic osteolysis and the immune system. Biomaterials. 2007 Dec;28(34):5044-8. https://doi.org/10.1016/i.biomaterials.2007.06.035

96. Kumazawa R, Watari F, Takashi N, Tanimura Y, Uo M, Totsuka Y. Effects of Ti ions and particles on neutrophil function and morphology. Biomaterials. 2002 Sep;23(17):3757-64. https://doi.org/10.1016/S0142-9612(02)00115-1

97. Taira M, Sasaki K, Saitoh S, Nezu T, Sasaki M, Kimura S, et al. Accumulation of element Ti in macrophage-like RAW264 cells cultured in medium with 1 ppm Ti and effects on cell viability, SOD production and TNF-alpha secretion. Dent Mater J. 2006 Dec;25(4):726-32. https://doi.org/10.4012/dmi.25.726

98. Wachi T, Shuto T, Shinohara Y, Matono Y, Makihira S. Release of titanium ions from an implant surface and their effect on cytokine production related to alveolar bone resorption. Toxicology. 2015 Jan;327:1-9. https://doi.org/10.1016/j.tox.2014.10.016

99. Mano SS, Kanehira K, Taniguchi A. Comparison of cellular uptake and inflammatory response via toll-like receptor 4 to lipopolysaccharide and titanium dioxide nanoparticles. Int J Mol Sci. 2013 Jun;14(7):13154-70. https://doi.org/10.3390/ijms140713154 
100. Ribeiro AR, Gemini-Piperni S, Travassos R, Lemgruber L, Silva RC, Rossi AL, et al. Trojan-like internalization of anatase titanium dioxide nanoparticles by human osteoblast cells. Sci Rep. 2016 Mar;6:23615. https://doi.org/10.1038/srep23615

101. Okuda-Shimazaki J, Takaku S, Kanehira K, Sonezaki S, Taniguchi A. Effects of titanium dioxide nanoparticle aggregate size on gene expression. Int J Mol Sci. 2010 Jun;11(6):2383-92. https://doi.org/10.3390/iims11062383

102. Tamura K, Takashi N, Kumazawa R, Watari F, Totsuka Y. Effects of particle size on cell function and morphology in titanium and nickel. Mater Trans. 2002;43(12):3052-7. https://doi.org/10.2320/matertrans.43.3052

103. Suárez-López Del Amo F, Rudek I, Wagner VP, Martins MD, O’Valle F, Galindo-Moreno P et al. Titanium activates the dna damage response pathway in oral epithelial cells: A pilot study. Int J Oral Maxillofac Implants. 2017 Dec;32(6):1413-20. https://doi.org/10.11607/jomi.6077

104. Bitar D, Parvizi J. Biological response to prosthetic debris. World J Orthop. 2015 Mar;6(2):172-89. https://doi.org/10.5312/wjo.v6.i2.172

105. Obando-Pereda GA, Fischer L, Stach-Machado DR. Titanium and zirconia particle-induced pro-inflammatory gene expression in cultured macrophages and osteolysis, inflammatory hyperalgesia and edema in vivo. Life Sci. 2014 Mar;97(2):96-106. https://doi.org/10.1016/i.lfs.2013.11.008

106. Senna P, Del Bel Cury A, Kates S, Meirelles L. Surface damage on dental implants with release of loose particles after insertion into bone. Clin Implant Dent Relat Res. 2015 Aug;17(4):681-92. https://doi.org/10.1111/cid.12167

107. Blum K, Wiest W, Fella C, Balles A, Dittmann J, Rack A, et al. Fatigue induced changes in conical implant-abutment connections. Dent Mater. 2015 Nov;31(11):1415-26. https://doi.org/10.1016/i.dental.2015.09.004

108. Klotz MW, Taylor TD, Goldberg AJ. Wear at the titanium-zirconia implant-abutment interface: a pilot study. Int J Oral Maxillofac Implants. 2011 Sep-Oct;26(5):970-5.

109. Stimmelmayr M, Edelhoff D, Güth JF, Erdelt K, Happe A, Bever F. Wear at the titanium-titanium and the titanium-zirconia implant-abutment interface: a comparative in vitro study. Dent Mater. 2012 Dec;28(12):1215-20. https://doi.org/10.1016/j.dental.2012.08.008

110. Souza JC, Barbosa SL, Ariza EA, Henriques M, Teughels W, Ponthiaux P, et al. How do titanium and Ti6Al4V corrode in fluoridated medium as found in the oral cavity? An in vitro study. Mater Sci Eng C. 2015 Feb;47:384-93. https://doi.org/10.1016/i.msec.2014.11.055

111. Souza JC, Henriques B, Ariza E, Martinelli AE, Nascimento RM, Silva FS, et al. Mechanical and chemical analyses across dental porcelain fused to CP titanium or Ti6AI4V. Mater Sci Eng C. 2014 Apr;37:76-83. https://doi.org/10.1016/j.msec.2013.12.030

112. Souza JC, Ponthiaux P, Henriques M, Oliveira R, Teughels W, Celis JP, et al. Corrosion behaviour of titanium in the presence of Streptococcus mutans. J Dent. 2013 Jun;41(6):528-34. https://doi.org/10.1016/i.jident.2013.03.008

113. Fretwurst T, Nelson K, Tarnow DP, Wang HL, Giannobile WV. Is metal particle release associated with peri-implant bone destruction? An emerging concept. J Dent Res. 2018 Mar;97(3):259-65. https://doi.org/10.1177/0022034517740560

114. Oliveira MN, Schunemann WV, Mathew MT, Henriques B, Magini RS, Teughels W, et al. Can degradation products released from dental implants affect peri-implant tissues? J Periodontal Res. 2018 Feb;53(1):1-11. https://doi.org/10.1111/ire.12479 